\title{
A táblagépes osztálytermi munka elemzésének lehetősége a Noldus Observer XT videós interakcióelemző program segítségével
}

A tanulmány a Társadalmi Megújulás Operatív Program IKT a tudás és tanulás világában - humán teljesítménytechnológiai (Human Performance Technology) kutatások és képzésfejlesztés címet viselő, TÁMOP-4.2.2.C-11/1/ KONV-2012-0008 azonosítószámú projekt keretében készült. A projekt az Európai Unió támogatásával, és az Európai Szociális Alap társfinanszírozásával valósult meg, és bemutatja a hozzáférés 1:1 modelljét, amely a BYOD modellel ellentétben elsősorban a táblagépekkel való oktatás keretrendszereként írják le. Az elméleti bevezetőt követően bemutatjuk a táblagépek iskolai alkalmazásának két lehetséges módját, és kiemelt figyelmet fordítunk az új elemzése lehetőség, a videós interakcióelemző szoftver, a Noldus Observer XT adta lehetőségekre.

Kulcsszavak: táblagép, iPad2, oktatás, e-biblioterápia, Noldus, Noldus Observer XT, videós interakcióelemzés

\section{Szerzői információ:}

Gulyás Enikő az Eszterházy Károly Fốiskola Neveléstudományi Doktori Iskolájának doktorandusz hallgatója, ahol kutatási területe a fejlesztố biblioterápia alkalmazásának lehetôsége a hazai oktatási rendszerben. Ennek keretében a módszert több aspektusból vizsgálja, így neveléstudományi, pszichológiai, szociológiai, irodalomtudományi szempontból is. Kiemelt figyelmet fordít a biblioterápia és az új technikai eszközök együttes alkalmazásának lehetôségeire, így a külföldön is kuriózumnak számító biblioterápia és iPad együttes, egymást segítő alkalmazásának módjára, a fejlesztố e-biblioterápiára.

Nagyné Klujber Márta gyógypedagógus, pedagógia-magyartanár Ma képzést követóen 2014-ben kezdte meg tanulmányait az Eszterházy Károly Fôiskola Neveléstudományi Doktori Iskolájában. Kutatási területe a tanulási képességek fejlesztésével összefüggó mozgásterápiák vizsgálata, amely során a videóval támogatott megfigyelések elemzésekor a Noldus Observer XT program használatával elemzi többek között a terápiás kapcsolatot, a terapeuta-gyermek interakció összetevóit.

Racsko Réka tanársegéd az Eszterházy Károly Fóiskola Médiainformatika Intézet Humáninformatika Tanszékén, valamint harmadéves doktorandusz az intézmény Neveléstudományi Doktori Iskolájában. Kutatási területe az elektronikus tanulási környezetek. Munkája során azt vizsgálja, hogy nemzetközi viszonylatban milyen eszközökkel és módszerekkel kerültek bevezetésre az IKTeszközök a köznevelésben (elsósorban K12 korosztály), valamint ehhez milyen humáneróforrás-feltételek szükségesek. Elkötelezett híve az újmédiának, számos ilyen jellegú kutatásban vesz részt, a kezdetek óta tagja a gyakorlóiskolában folyó pedagógiai kísérleteknek. A kvalitatív kutatások mellett szívesen foglalkozik kvantitatív eszközökkel (kérdôívekkel) és a web 2.0 oktatást segítô lehetőségeivel. 


\section{Így hivatkozzon erre a cikkre:}

Gulyás Enikő, Nagyné Klujber Márta, Racsko Réka. „A táblagépes osztálytermi munka elemzésének lehetősége a Noldus Observer XT videós interakcióelemző program segítségével”.

Információs Társadalom XV, 1. szám (2015): 81-94.

https://dx.doi.org/10.22503/inftars.XV.2015.1.5 ए

A folyóiratban közölt müvek

a Creative Commons Nevezd meg! - Ne add el! - Így add tovább! 4.0

Nemzetközi Licenc feltételeinek megfelelően használhatók. 
Gulyás Enikő - Nagyné Klujber Márta - Racsko Réka

\section{A táblagépes osztálytermi munka elemzésének lehetôsége a Noldus Observer XT videós interakcióelemzó program segítségével ${ }^{1}$}

\section{Bevezetés}

Az IKT-eszközök oktatásba való integrálása vezetô trendként jelenik meg a kormányzati politikában, mint a digitális befogadás, a társadalmi integráció és a tanulási lehetôségek kiszélesítésének alternatívái (Nemzeti Infokommunikációs Stratégia 2014-2020; The NMC Horizon Report: 2013 Higher Education Edition). Az ehhez kötôdô kísérletek és kutatások nélkülözhetetlenek egyrészt hatékonyságuk megítélésében, másrészt a megfelelố használat megalapozása érdekében is.

Az elektronikus tanulási környezet kiépítése az Eszterházy Károly Foóiskola Gyakorló Általános, Közép-, Alapfokú Múvészeti Iskolájában több éves múltra tekint vissza, már 2010-ben, az e-papír program keretében e-könyv olvasókat kaptak a 7. és 11. évfolyamos tanulók, amelyek újabb utat nyitottak számukra a tanulásban. A technika változását figyelemmel kísérve 2012-ben iPad2-es eszközökön tanulhattak a 8. osztályosok, 2014-tól pedig a 3., 6. és 9. évfolyam diákjai.

Jelen tanulmányunkban a 3. osztályos diákok eszközhasználatának, valamint a 6. osztályos tanulók fejlesztố e-biblioterápiás foglalkozásainak elemzésének eredményeit kívánjuk bemutatni, amelyek a szövegértés fejlesztésének különbözó aspektusait kívánják fejleszteni. Az érvényben levó Nemzeti alaptantervben és az adott kerettantervben, valamint az ezekre épüló iskolai programban megfogalmazott fejlesztési célok és feladatok során elótérbe került a magyar nyelv és irodalom tanítása kapcsán, a 3. osztályban kiemelt fejlesztési feladatként, a különféle források használata, valamint az információszerzés különbözố lehetôségeinek és korlátainak megismertetése. Úgy véljük, hogy a kísérletben használt szövegértést fejlesztố munkafüzet, a hagyományos tankönyv, valamint a böngészôprogram és az iPad2 egyéb applikációi által nyújtott lehetôségek nagymértékben segítik az ezeknek való megfelelést.

A magyar nyelv és irodalom tantárgyban kitûzött nevelési-fejlesztési célok alapján a 6. osztály több szempontból is kiemelten fontos, úgymint a véleménynyilvánítás, érvelés, érzelmek azonosítása, szövegértés, következtetések megfogalmazása, a képzelet, a kreativitás, a szóbeli kommunikációs készségek fejlesztése, a múvekben szereplók kapcsolatainak megértése. A 6. osztály fontosságára az is felhívja a figyelmet, hogy a kompetenciamérések is érintik ezt az évfolyamot. Mindezen elvárások és célok megvalósításához jelentôs mértékben hozzájárulhatnak a fejlesztő e-biblioterápiás foglalkozások.

\footnotetext{
${ }^{1}$ Kutatási forrás:

“A tanulmány a Társadalmi Megújulás Operatív Program IKT a tudás és tanulás világában - humán teljesítménytechnológiai (Human Performance Technology) kutatások és képzésfejlesztés címet viselő, TÁMOP-4.2.2.C-11/1/KONV-2012-0008 azonosítószámú projekt keretében készült. A projekt az Európai Unió támogatásával, és az Európai Szociális Alap társfinanszírozásával valósult meg.”
} 
A táblagépek e két évfolyamban történơ alkalmazása megítélésünk szerint jól kiegészíti egymást és nagymértékben fejleszti a tanulói kreativitást a szöveg- és képalkotási (storyboard) gyakorlatok révén.

Tanulmányunkban a táblagépes oktatás elméleti hátterének aktuális trendjeit követôen, röviden bemutatjuk az e-biblioterápiás kísérlet történeti hátterét, majd a kutatás céljait, a vizsgált mintát valamint az alkalmazott módszert, illetve a kapott eredményeket. A tabletek alsó tagozatban való alkalmazása szintén hangsúlyos terület, hiszen a szövegértés fejlesztésében jó eredménnyel alkalmazhatóak az interaktív tankönyvek. Kutatásunkban az interakciók elemzése során a tanár-eszköz, tanuló-eszköz, valamint a tanár-tanuló kapcsolatát vizsgáljuk.

Az eredmények elemzésére újabb lehetôséget biztosít a Noldus Observer XT interakcióelemzố szoftver, amelynek a külföldi gyakorlatban történó alkalmazásáról már számos cikket olvashatunk (Oliveira-Pinho, 2013, Ruiz-Sancho-Frojan-Parga, 2013, Tafforin, 2013, Reyna-Brown, 2012). Az olyan hazai kutatási beszámolók azonban, amelyek a széles közönség számára elérhetôek lennének, csak igen szerény számban jelentek meg.

A bemutatott és elvégzett elemzés nem kíván mély pedagógiai következtetéseket megfogalmazni, célja a kutatási folyamat kidolgozása, illetve a módszer bemérése volt.

\section{A személyes tanulási környezetek és az 1:1 hozzáférés modellje}

Elôször az információs és kommunikációs technológiával bôvített tanulási környezet jellemzóit tekintjük át, mivel kutatásunk mindkét konkrét vizsgálata ilyen környezetben zajlott.

A személyes tanulási környezetek kialakításában központi szerepet tölt be a BYODmodell mellett az 1:1 modell, amelyet a szakirodalom a hozzáférés modelljeként definiál.

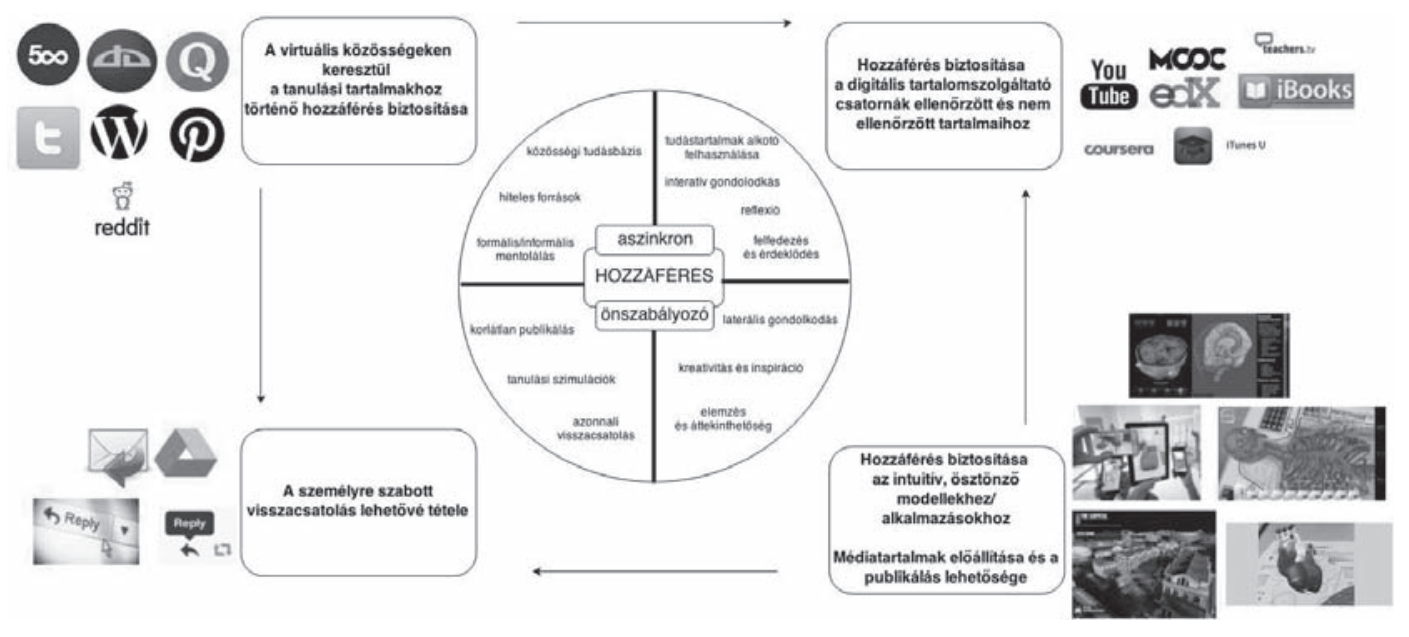

1. ábra Az 1:1 modell részei (Saját fordítás)

Forrás: http://www.teachthought.com/wp-content/uploads/2014/03/ipad-1-to-1-model.jpg 
A modellt elsôsorban a táblagépekkel való oktatás keretrendszereként írják le, amely a tabletek erôsségeire épülnek, vagyis a tartalmak egyfajta csatornájaként, modelljeként és az azonnali visszacsatolás eszközeként jelenik meg. A legtöbb esetben ezen hozzáférés aszinkron módon történik és önállóan megy végbe. A legfontosabb tényezó a táblagépek oktatásban való használatánál a tanulási folyamat újragondolása, amely során minden fél számára biztosított az 1:1 képernyô-hozzáférés lehetốsége, amely lehetôvé teszi a mobilitás és a személyre szabott tanulási környezetet. Az oktatási tartalmakhoz való folyamatos (24/7) hozzáférés által a tanulási folyamat is önszervezôdoové és személyes irányításúvá válik.

A tanulók olyan forrásokhoz is hozzáférhetnek a világhálón, amely az információs múveltség fejlesztésének eszköze lehet, hiszen a tudatos és kritikus információfogyasztáson kívül, a felfedezéses és más tevékenységekbe ágyazott tanulás képességére is szükségük lehet. Az eszközökön elérhetô források fejlesztik a kreativitást és megfelelő tanári irányítás mellett a tanulók tantárgyi koncentrációk során elsajátított interdiszciplináris ismereteket is jobban átlátják, a Robinson-effektusról nem is beszélve.

A modell négy fó részból áll:

\section{A virtuális közösségeken keresztül a tanulási tartalmakhoz történố hozzáfé- rés biztosítása}

A tanulók bizonyos szolgáltatásokon keresztül hozzáférhetnek olyan eredeti, hiteles tartalmakhoz, amelyeket virtuális közösségek hoznak létre, mindenféle témában. A közösségekhez a tanulók szabadon csatlakozhatnak érdeklôdési körüknek megfelelóen, ahol megoszthatják gondolataikat más hasonló érdeklődésú egyénekkel, nem is beszélve az aktív tanulás önképzố erejéról, amely e közösségeket jellemzi. Ilyen alkalmazások például a Reddit, a Twitter, az 500 px, a Devianart vagy a Quora.

A Reddit egy közösségi weboldal, ahol a regisztrált felhasználók megoszthatják híreiket, képeiket és cikkeiket, illetve értékelhetik a már meglévóket. A "reddit” szó egy szójáték az angol "read" (olvas) és "edit" (szerkeszt) szavakból, valamint a "read it" (elolvassa/elolvasta) kifejezésból származik. Lehetôség van a tartalmak elmentésére is, ekkor a felhasználó profiljába kerül a megjelölt link/bejegyzés, hogy a továbbiakban könnyen elérhesse azt. (Wikipédia, 2015)

Ezen felületek lehetôvé teszik a szakmai közösségekhez való tartozást, és az abban való kapcsolatépítést.

\section{Hozzáférés biztosítása a digitális tartalomszolgáltató csatornák ellenốrzött és nem ellenórzött tartalmaihoz}

A tanulók a digitális tartalomszolgáltatókon keresztül számos tartalomhoz hozzáférhetnek. Ezek egy része nem szúrt tartalom, ilyen például a Youtube, míg a tömeges online kurzusok (MOOC-Massive Online Online Course) keretében múködő edX, Coursera és más OpenAccess hozzáférésú tanulási tartalmak ellenórzött forrásokat tartalmaznak. A másik ága ezen tartalmaknak a digitális tankönyvek, mint az iBooks Author-rel szerkesztó interaktív anyagok, vagy az iTunes U, illetve a nyílt hozzáférésú Teachers Tv videótartalmai, valamint oktatási segédanyagai, és egyéb tudásbázisok. Az ezeken keresztül elért információk hozzásegíthetik a tanulókat a tartalmak tudatos és kritikus kiválasztásához, továbbá felhasználásuk etikus módjainak megismeréséhez. 


\section{Hozzáférés biztosítása az intuitív, ösztönzố modellekhez/alkalmazásokhoz}

Ezen lehetóségek során a tanulók olyan szimulációkat, modelleket, animált ábrákat érhetnek el, amelyek segíthetik a kreativitás, a dizájn és a teljesítmény területén tevékenykedő tanulótípusok munkáját, ötletgyújtését. Olyan alkalmazások állnak ugyanis napjainkban rendelkezésre, amelyek a kiterjesztett valóság technológiáján alapulva megtekinthetôvé teszik az emberi testet négy dimenzióban, vagy az ókori Róma nevezetes helyszíneit. E technológiák segítik a háttértudás elmélyítését és fejlesztenek számos egyéb kompetenciát, készséget, képességet (pl. térszemlélet).

\section{A személyre szabott visszacsatolás lehetôvé tétele}

A saját eszköz (képernyố) lehetôvé teszi az azonnali visszacsatolást a különbözô alkalmazásokon keresztül, amelyet egy nagyobb osztályteremnél nem tudnánk megtenni. Ezáltal a tanárnak új lehetôségei nyílnak meg ezen a területen.

A modell ismeretében az érdekelt minket, hogy az újonnan alkalmazott taneszközök és eljárások hogyan befolyásolják egyrészt a tanórák menetét az óraszervezés szempontjából, illetve a tartalmi feldolgozás során az egyéni viszonyulásokat, mint például a motiváltság, részvétel.

\section{Táblagépes kutatás alsó tagozatban saját fejlesztésú munkafüzettel}

\section{A kutatás elốzményeinek, hátterének bemutatása}

A köznevelés felsố tagozatában alkalmazott táblagépek módszertani kísérlete a 2011/2012es 1. félévre nyúlik vissza az Eszterházy Károly Fóiskola Általános, Közép-, Alapfokú Múvészeti Iskolájában. Ekkor a tableteket, mint újmédia eszközöket alkalmaztuk a Médiainformatika Intézet tagjaiból, valamint a gyakorló pedagógusokból álló kutatócsoport szakmai támogatásával, amelynek elsốdleges célja az oktatást segítố alkalmazások pedagógusokkal való megismertetése, és ez által a módszertani kultúrába való beépítése volt. A 8. C osztályban a tanulók emellett a Nemzeti Tankönyvkiadó tankönyveit is használták, azonban ekkor még statikus PDF-formátumban. Célunk a hagyományos tankönyvek és az új platformon elérhetố tartalom szimbiózisa volt. A kutatás során felmértük, hogy a táblagépek köznevelésben történó beválása milyen feltételek mellett valósulhat meg, illetve mely tanulást segítő applikációt tehetnék a motiváción túl hatékonyabb az oktatást. A kutatást technikai és módszertani inkubációval is támogattuk, amelynek keretében a projektbe bevont pedagógusok segítséget kaptak felmerülő problémájuk megoldásában és szakmai fejlódésük elómenetelében. A bevont tantárgyak a következóek voltak: angol, biológia, földrajz, fizika, informatika, kémia, magyar irodalom, matematika, mozgóképkultúra és médiaismeret, történelem. A tanulók az eszközöket csak az iskolában használhatták, azok hazavitelére nem volt lehetôségük.

A kutatás következố fázisa a 2012/2013. 1. félévben kezdődött, amikor a korábbi statikus tankönyveket felváltották az interaktív iBooks tankönyvek, amelyeket az Eszterházy 
Károly Fốiskola Médiainformatika Intézetének fejlesztố csapata és a kutatásba bevont pedagógusok együtt dolgoztak ki. A tankönyvek szakmai alapját a Nemzeti Tankönyvkiadó tananyagai alkották, amelyeket mediatizáltak a fejlesztók a pedagógusok instrukciói alapján, valamint az újonnan fejlesztett, tudásellenốrzést lehetôvé tevő eleme (pl. interaktív tesztek) kidolgozását végezték el. A hagyományos, papíralapú tankönyvet a kísérlet idejére mellózték a napi iskolai gyakorlatban a 8. D osztály esetében. A tapasztalatok azt mutatják, hogy az interaktív tankönyvek használata kibóvítette a tanulási-tanítási lehetôségek tárházát, azonban sok esetben a platformfüggóség (a tankönyveket csak iPad eszközökön lehet megtekinteni) gátat is szabott a lehetôségeknek. A másik nehezítố tényezốt ezen túlmenốen az eszközök hazavitelének hiánya jelentette, ugyanis az otthoni felkészülés során nem tudták a tanulók igénybe venni az interaktív tankönyv nyújtotta lehetôségeket.

A táblagépek és az interaktív tananyagok alkalmazásának egy kibóvített koncepciója indult el a 2013/2014-es tanévben, amelynek keretében az 1., 3., 6., és 9. évfolyam egyegy osztálya használt táblagépet. A 9. osztályban Samsung táblagépek, a többi osztályban iPad2 eszközök álltak a diákok rendelkezésére. Az 1. osztályos tanulók esetében a projekt kísérleti jellege még inkább szó szerint értendô, hiszen az elsố osztályos tanulók esetében kiemelten fontos az írástanulás során a finommotoros mozgások elsajátítása, így ebben a korosztályban inkább csak gyakorlásra használják az eszközt. A 3. osztály esetében Molnár Lászlóné szakvezetố kézirata alapján saját fejlesztésú munkafüzet készült (éRTEm munkafüzet), amellyel a szövegértés gyakorlását és fejlesztését segítik eló. A munkafüzet interaktív formában tartalmaz feladatokat, illetve a hallás utáni szövegértés gyakoroltatására hangos könyvek állnak a tanulók rendelkezésére. A 6. osztály számára is hasonló szellemben készített a Médiainformatika Intézet kutatócsoportja saját fejlesztésú munkafüzetet, azonban a szaktárgyi érintettség tekintetében a természettudományos területek kerültek a fejlesztés fókuszába.

\section{A kutatás kérdései}

A kutatás célja, hogy megvizsgáljuk, milyen mentális tényezók befolyásolják az eszközök használatát, a használat szintjét, és milyen tényezók befolyásolják a hozzájuk fúzoódő attitúdöt. Ezen túlmenốen vizsgáljuk a technikai felkészültség szintjét és a mentális tényezók hatásait, szerepét az attitûdváltozásban. Célunk feltárni, hogy a használat szintje és menynyisége között milyen összefüggések figyelhetốek meg, illetve kutatjuk a pedagógiai stratégia változásait az IKT eszközök használatának hatására. Az egész kutatás során nagy hangsúlyt kapott az immunkompetencia (Bredács—Kárpáti, 2012) szint változásainak vizs-

\footnotetext{
${ }^{2}$ Az eszközök hazavitelének kérdése hazánkban az eszközbiztosítások kidolgozatlansága és az anyagi felelôsség vállalásának kérdése nem tisztázott.

${ }^{3}$ Szerzók: (természetismeret: biológia, földrajz, kémia, fizika): Forgóné Stupek Ilona, Sándorné Halász Erzsébet, Sósné Cseplye Magdolna Tóthné Szük Erzsébet. Közremúködók: Csanádi Péter, Csernai Zoltán, Czeglédi Tamás, Koronczi Melinda, Mogyorósiné Herczeg Éva, Szlahorek András, Tóth Ferenc Zsolt
} 
gálata az IKT-eszközhasználat hatására. Az eredmények alapján javaslattételek kidolgozását tervezzük annak tekintetében, hogy milyen módszerek, változtatások szükségesek a pozitív tanári motiváció kialakításához.

A kutatás kérdései az interakcióelemzés vonatkozásában:

- Milyen gyakran kerül a tanári instrukciókban a munkafüzet a tevékenység közvetlen és közvetett fókuszába?

- Milyen gyakorisággal és milyen formában (közvetlenül, közvetve) használják a tanulók a munkafüzetet és a táblagép egyéb alkalmazásait (kiemelten a böngészót)?

\section{Kutatási módszerek}

Az alsó tagozatos tanulók olvasásértésének fejlesztését, a kutatás idődimenzióját tekintve keresztmetszeti, trendvizsgálat, folyamatos megfigyelés formájában végezzük, különbözó módszerekkel. Az alábbi tanulmányban a megfigyelés módszerét szeretnénk új formában, interakció-elemzésekkel bemutatni, a Noldus Observer XT szoftver segítségével.

A kutatás során videós órafelvételek készítését kértük a pedagógusoktól, tantárgyanként minimum két felvétel keretében. Az általunk elemzett órák 2014. május 7. és 24-i idôpontokban kerültek felvételre a Líceum Televízió operatoórei által, két kameraállásból. Az órafelvételek esetében e két idôpontot az interaktív munkafüzet használata mellett az a módszertani megfontolás indokolta, hogy követố megfigyelés révén egymás utáni idôintervallumban lévó felvételek kerüljenek elemzésre. A kutatás folytatásának egyik alternatívája lehet a longitudinális vizsgálatok lefolyatása, hiszen az általunk végzett keresztmetszeti vizsgálatoknál jóval alaposabb összefüggések feltárására van ezáltal lehetőség.

\section{Noldus elemzési módok, próbák}

A tanórákról készült videofelvételek megfigyelési alanyai a tanár, illetve a diákok voltak. A kódolás során jeleztünk minden, a verbális kommunikációban megjelenó közvetlen és közvetett utasítást, amely az elektronikus munkafüzet, vagy a hagyományos füzet használatára vonatkozott. A kódolási folyamatban a pontos idóbeli kezdet és lezárás rögzítése is lehetséges volt.

A tényleges óraelemzést megelőzte több próbatesztelés, melyek a program megfeleló használatához szükséges ismeretek és készségek elsajátítását szolgálták, a megfigyelók felkészítését és a megfelelő elemzési séma kidolgozását tették lehetôvé.

A megfigyelést két tesztelő végezte két eltérô tanórai helyzet kódolásával.

\section{Az eredmények bemutatása és értelmezése}

A kódolás befejezését követôen az analízis során többféle beépített statisztikai eljárás automatikusan generál eredményeket. Az alapvetố elemzési modullal, az idốtartam figyelembevételével gyakoriság, idôtartam, középérték, valamint százalékos megoszlás volt kiszámítható. 
A statisztikai elemzés a következố számszerú eredményeket mutatta.

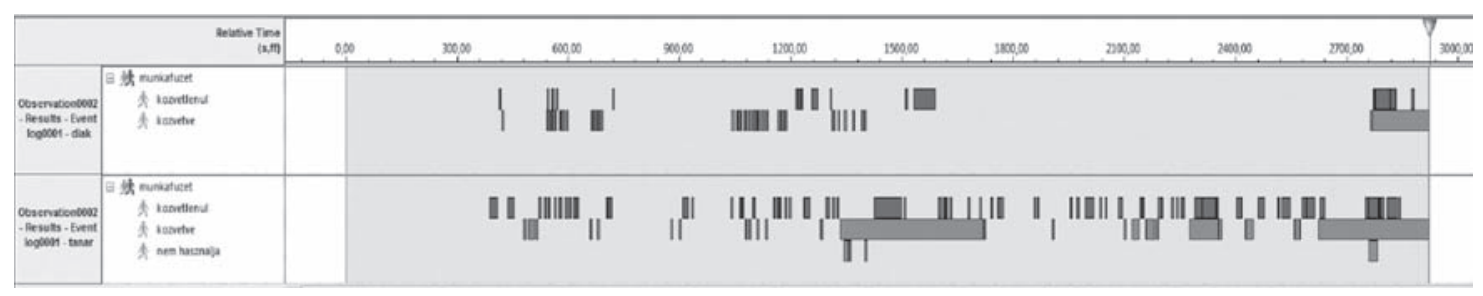

\section{2. ábra Az elsố tanóra interakció-elemzése}

Az elsố megfigyelés (2. ábra) esetén a diákok kizárólag az elektronikus munkafüzet használatára tettek utalásokat verbális kommunikációjuk során közvetlenül 5 alkalommal (középérték szerint 138,75 sec. idótartamban), közvetett formában 3 alkalommal (23 sec.), ezek a teljes tanóra közel 17 \%-át tették ki. A tanári megnyilvánulások közvetve 28 alkalommal vonatkoztak a munkafüzet használatára $(9,60 \mathrm{sec}$.), közvetlenül 15 alkalommal (6,85 sec.). A tanárok a hagyományos füzet használatát összesen 7 alkalommal jelezték. A tanári közlés szintén közel 13,5 \%-ban fordult eló a teljes megfigyelési idóben. Az eredmények értelmezésével tehát megállapítható, hogy a diákok kevesebb alkalommal utaltak verbálisan az elektronikus munkafüzet használatára, azonban hosszabb ideig tartott a megszólalás, mint a tanár esetében. A tanárt rövid utasítások jellemezték, azonban náluk a hagyományos füzetekre való utalás is megjelent, azonban összességében a tanulói utalások töltötték ki nagyobb százalékban a tanóra idótartamát.

\begin{tabular}{|c|c|c|c|c|c|c|c|c|c|c|c|c|}
\hline & 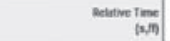 & 0,00 & 3000 & $00, \infty$ & $\$ 0,0,00$ & 120000 & 1800,00 & andor & 20000 & 20000 & 20000 & 3000000 \\
\hline 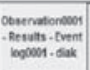 & 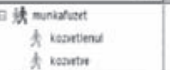 & & & & & & I & & I & & & I \\
\hline 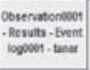 & 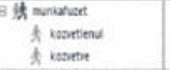 & & 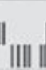 & & & & & & 1 & & & I \\
\hline
\end{tabular}

3. ábra A második tanóra interakció-elemzése

A második megfigyelés (3. ábra) esetén a diákok részéról legnagyobb arányban a közvetett utalások fordultak eló nagyobb arányban, a munkafüzetre 29 alkalommal (8,83 sec.), míg a böngészố használatára 17-szer utaltak (átlagosan 2,26 sec.). Közvetlenül mindkét taneszközre egyformán, 9 alkalommal történt verbális utalás, amely a tanóra idejének 6,5\%-át tette ki. A közvetett utalás $10 \%$-ra tehetố.

Az elemzett óra során a tanár közvetve utal a böngészốre 6-szor, a munkafüzetre 19-szer. Közvetlenül a munkafüzetre 53, a böngészóre 17, legkevesebbszer a hagyományos füzetre 2 alkalommal utal. Az adatokból jól látszik, hogy a tanulók ebben a csoportban sem említik a hagyományos füzetet, s ez a tanár esetében is elhanyagolható. Az elemzésból kitúnik, hogy a tanári instrukciók az óra egész idốtartamát tekintve nagyobb arányban jelennek meg, mint a diákok megszólalásai a taneszközre vonatkozóan. Emellett azt is megállapíthatjuk, hogy a tanári oldalról 97-szer történt utalás, a diákok esetében pedig 64 alakommal mondható el a taneszköz vonatkozásában. 
Kutatási probléma szempontjából a következő ábra mutat informatív eredményeket, jól szemléltetve a statisztikai elemzés adatait. Az alábbi ábrán (4. ábra) az egyik megfigyelés (observation0002) verbális utasításra vonatkozó, alanyonként szétbontott gyakorisági táblázata található az idôpontok függvényében. A percenként jelölt idôskálán ötperces beosztás található, így vizuálisan jól követhetô az események elófordulása.

\begin{tabular}{|c|c|c|c|c|c|c|c|c|c|c|c|}
\hline & hetator $\lim _{\text {is }}$ & $\infty, \infty$ & $m, \infty$ & $m_{0} \infty$ & 1200000 & 1500000 & 100000 & $20 \times 00$ & $2 n e 00$ & 20000 & 20000 \\
\hline 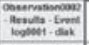 & 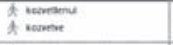 & & II & & II & & & & & $\pi 1$ & \\
\hline 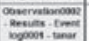 & 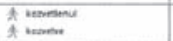 & & 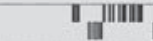 & & TI & & & & & & \\
\hline
\end{tabular}

4. ábra A gyakoriság és idóbeli elófordulás megoszlása (tanár, diák, közvetve és közvetlenül utalás a böngészőre)

Az ábra a statisztikai adatok vizuális megjelenítésével szemléletesen mutatja be a közvetett és közvetlen utasítások megjelenését, annak pontos idôpontját és idôtartamát, s ezek kronologikus egymásutániságát a tanári és a diákok oldaláról. Világosan követhetô a közvetett és a közvetlen utasítások gyakoriságának változása.

Az időskála emellett láthatóvá teszi azt is, hogy a második tanóra esetében az óra elsố öt percében nem történik semmiféle utasítás a taneszközök használatára, azonban az óra legnagyobb részében folyamatosan történnek utalások mindkét megfigyelt alany szempontjából. A diákok visszacsatolásainak gyakoriságából arra következtethetünk, hogy a tanóra interaktív részesei. Az elsố megfigyelés során az összehasonlításban a diákok verbális kommunikációs viselkedése jóval kisebb aktivitást mutat a teljes tanórai folyamatban.

\section{A fejlesztố e-biblioterápiás foglalkozás jellemzôi}

A nevelési-oktatási intézményekben egyre inkább helyet követelnek maguknak az informális tanulási lehetôségek, amelyek több területen is fejlesztik a diákokat anélkül, hogy azok ezt észrevennék. Az egész napos iskola alkalmat biztosít a diákok aktív kikapcsolódására, valamint ezen informális tanulási tevékenységek kibontakozására. Egy ilyen lehetséges módszer a fejlesztô biblioterápia, valamint annak 21. századi adaptációja, a fejlesztô e-biblioterápia.

A fejlesztő biblioterápia egy külföldön széles körben alkalmazott módszer. Múltja egészen az ókorig visszavezethetó, tudatos alkalmazása azonban a XIX. századig váratott magára, ekkor azonban gyorsan elterjedt, s már nem csupán pszichiátriai osztályokon, szociális otthonokban, gyermekotthonokban alkalmazták, hanem könyvtárakban, iskolákban is. Ma már alkalmazási területe igen gazdag, olvashatunk tanulmányokat a módszer tanulási nehézségekkel küzdő gyerekek (Prater, 2003) körében történó alkalmazásáról, vagy a homoszexuálisok és a másság elfogadása (Norton-Vare, 2004) érdekében történó használatáról, de olyan kortársproblémák feldolgozásában, mint erốszakosság, is segíthet (Larson és Hoover, 2012).

Ma már nem meglepó, ha nem a hagyományos értelemben vett formában ismerkednek meg a választott irodalommal a foglalkozáson a résztvevók. Használnak képregényeket (Gavigan, 2012), vagy épp a tananyag feldolgozásába építik be, a tudás elmélyítését célozva meg (Sanacore, 2012). 
A technológiai változások a biblioterápiát sem kerülhették el, így felmerült az igény, az új eszközök biblioterápiás foglalkozásokba integrálására, ezért hoztuk létre a fejlesztő e-biblioterápiát (Gulyás, 2015).

\section{Célok, hipotézisek}

A foglalkozássorozat célja az volt, hogy az iPad és a biblioterápia közös alkalmazásának egy lehetséges módját kipróbáljuk, és a foglalkozássorozat során bekövetkezố változásokat rögzítsük. Ennek megfelelôen a hosszú távú hatások mérésére a Thomas-Kilman-féle konfliktuskezelési tesztet, valamint a Coopersmith-féle önértékelés tesztet használtuk (Gulyás, 2015). Az egyes foglalkozások rövid távú hatásának detektálását egy saját készítésú attitûdskála biztosította. A diákok interakcióinak elemzését a foglalkozások videofelvételének Noldus Observer XT segítségével végeztük el, ez utóbbi tapasztalatáról olvashatnak tanulmányunkban beszámolót.

Hipotéziseinket a következóképpen fogalmaztuk meg a fejlesztố e-biblioterápiás foglalkozásokkal kapcsolatban az interakció-elemzés vonatkozásában:

- Az e-biblioterápiás foglalkozássorozat elején a diákok helyváltoztatása gyakoribb

- Az e-biblioterápiás foglalkozássorozat végére a diákok metakommunikációs jelzései nagyobb fokú nyitottságra utalnak

\section{Minta}

Az Eszterházy Károly Fóiskola Gyakorló Általános, Közép-, Alapfokú Múvészeti Iskolájának 6. osztályos tanulói, akik a tananyag elsajátításához iPadet használnak. A diákokat két csoportba osztottuk, így az osztálynévsor elsố fele a kontroll ( $\mathrm{N}=11)$, még a második fele a beavatkozási $(\mathrm{N}=11)$ csoportba került. Ezáltal mindkét csoport heterogén volt nem, tanulmányi eredmény, magaviselet, társakkal való kapcsolat, valamint családi háttér szempontjából. Jelen cikkünkben a beavatkozási csoportban bekövetkezố változásokat kívánjuk bemutatni.

\section{Eszköz / Módszer}

Hogyan is nézett ki a gyakorlatban a fejlesztô e-biblioterápiás foglalkozás? A foglalkozás elején a foglalkozásvezetố felolvasta a diákoknak a kiválasztott múvet, majd ezt követôen a tanulók a hallott történethez készítettek az iPad segítségével egy képet, amely lehetett a hallottak interpretációja, továbbgondolása, átgondolása. Fontosnak tartottuk, hogy azt a képet próbálják vizuális formába önteni, amely a mú hatására kialakult a fejükben. Ezeket a képeket lementették, és e-mailben elküldték a foglalkozásvezetônek, aki egy interaktív tábla segítségével mindenki számára láthatóvá tette óket. Ezt követte a mú és a képek közös szóbeli feldolgozása a foglalkozásvezetố segítố kérdéseinek irányításával. A diákok elmondhatták gondolataikat, ötleteiket, élményeiket, tapasztalataikat. A foglalkozás során támogattuk a konstruktív viták kialakulását. A foglalkozás végén közösen összefoglaltuk 
a beszélgetést, és megfogalmaztuk a konklúziót. A 4 alkalomból álló e-biblioterápiás foglalkozássorozat során az alábbi múvek szolgáltak a beszélgetés elôiidézốjeként:

- $\quad$ Koreai népmese: Kam tükre

- $\quad$ Európai népmese: Öregasszony az ecetesüvegben

- Móra Ferenc: Két forintos

- Ismeretlen szerzố: Miért van az ember szíve rejtve?

\section{Eredmények}

A Noldus Observer XT program segítségével az 1. és a 4. foglalkozás videofelvételeit kódoltuk be az alábbi kategóriák szerint: áll-ül, mosoly, harag, keresztbe tett láb, karba tett kéz. Azért tartottuk fontosnak e kategóriák felvételét és összehasonlítását, mert úgy gondoltuk, hogy a foglalkozások elórehaladásával a keresztbe tett láb és a karba tett kéz egyre ritkábban fog megjelenni, ugyanis a testbeszéd hagyományos értelmezése során ezeket a védekezó és/vagy negatív magatartás megnyilvánulásainak tekintjük. Hasonló megfontolásból került a kódolási listára a mosolygás is, ugyanis azt feltételeztük, hogy a foglalkozások hatására a résztvevô diákok egyre nyitottabbak, pozitívabb a hozzáállásuk a beszélgetéshez, és ez meg fog jelenni abban is, hogy hányszor és mennyi ideig mosolyognak. Mivel a fejlesztô biblioterápiás foglalkozásokon több érzelem is elófordulhat, hiszen érinthetünk olyan témát, amely felkavarja a résztvevóket, ezért számítottunk rá, hogy a harag is meg fog jelenni, bár ennek megnyilvánulása az idố elốrehaladtával kevésbé lesz intenzív. A helyváltoztatás detektálását azért tartottuk fontosnak, mert úgy gondoltuk, hogy az elsó foglalkozáson, amikor még több probléma adódhat a program használatával, az e-mail elküldésével, a diákok többször fognak felállni, és odamenni társaikhoz segíteni, mint a késóbbi foglalkozásokon. A felállás a késóbbiekben már csupán akkor jelent meg, amikor az interaktív táblához mentek valamit megmutatni, vagy eljátszották, hogyan viselkedik velük az egyik pedagógus. Az 5. és 6. ábrán látható, hogy a diákok és a foglalkozásvezetố milyen megoszlásban állt fel és ült le az elsố és az utolsó foglalkozás során (a foglalkozásvezetố a 0 . bekódolt személy az ábrán).

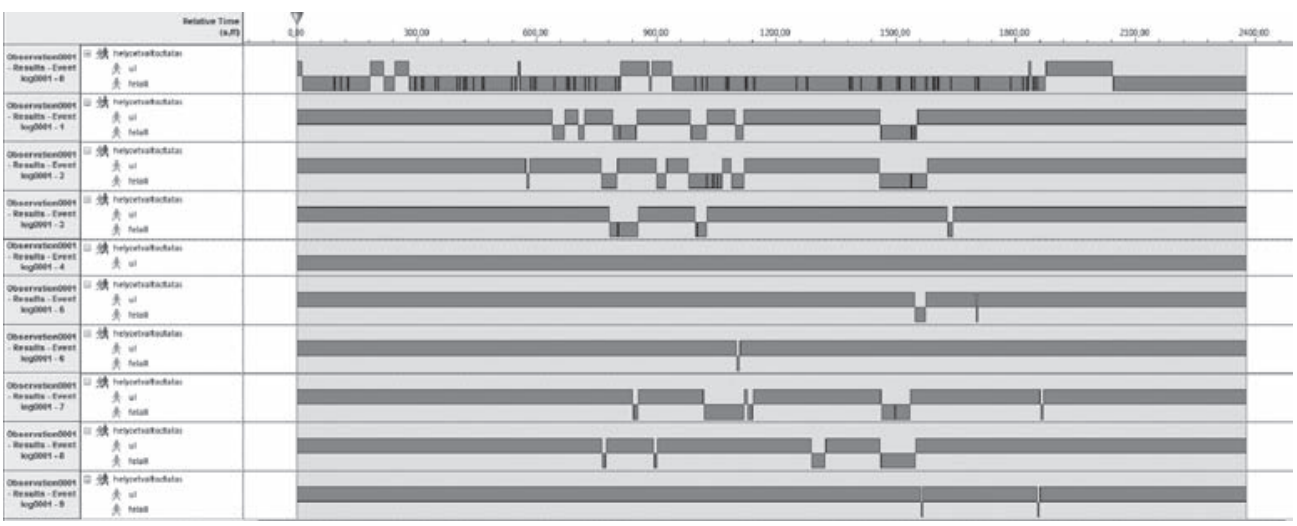

5. ábra 1 . foglalkozás - a foglalkozásvezetố és a foglalkozáson résztvevố diákok helyváltoztatása az 1 . foglalkozáson 


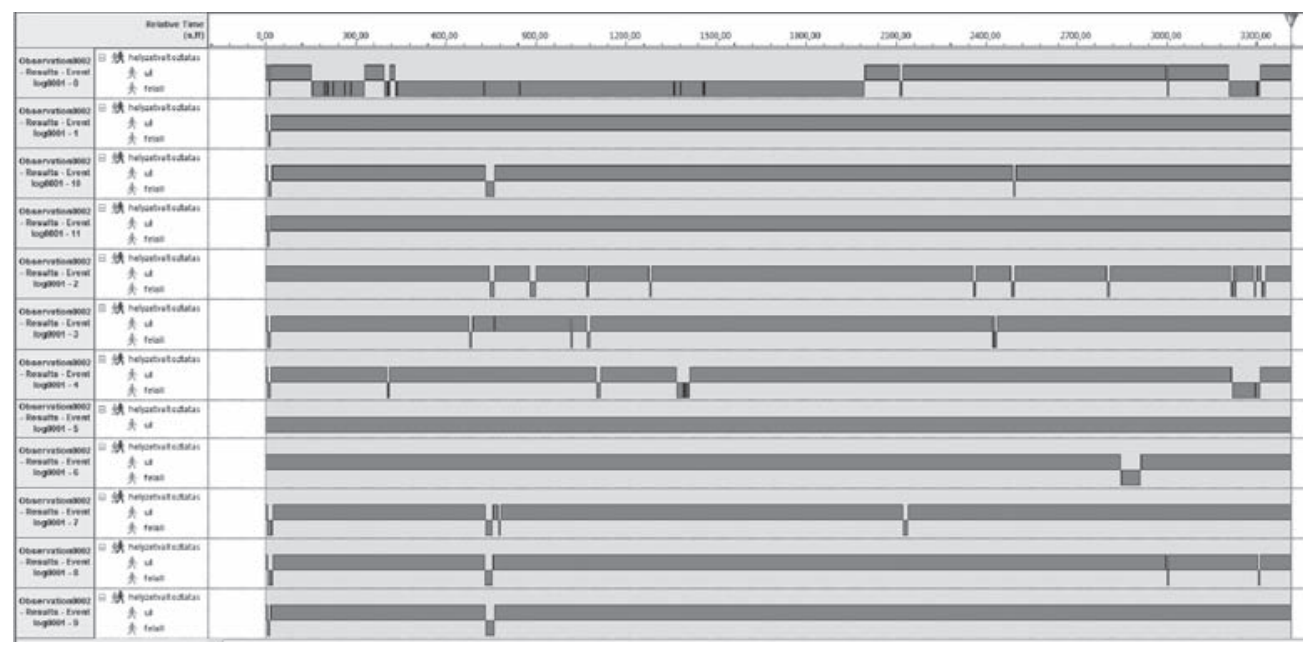

6. ábra 4. foglalkozás - a foglalkozásvezetố és a foglalkozáson résztvevố diákok helyváltoztatása a 4. foglalkozáson

A kódolás adataira elvégzett t-próba alapján elmondhatjuk, hogy a részt vevố diákok mosolygásának összes száma az első foglalkozáshoz viszonyítva szignifikánsan növekedett ( $\left.t^{\prime}=-4,205, p=0,003\right)$. A legtöbbször mosolygó (3) diák az elsố foglalkozás során 58 alkalommal mosolygott, és ennek százalékos megoszlása a megfigyelés teljes idôtartamához viszonyítva azt mutatja, hogy az adott diák (3) a foglalkozáson 21,90 \% idốtartamban mosolygott. Az utolsó foglalkozáson ugyanez a diák (3) 73 alkalommal mosolygott, és ennek százalékos megoszlása a megfigyelés teljes idôtartamához viszonyítva 35,72 \% volt. Az elsố foglalkozáson legkevesebbet mosolygó diák (4) 9 alkalommal mosolygott, ami a megfigyelés idótartamának 2,57 \%-a volt. Ugyanezen diák (4) az utolsó foglalkozáson 46 alkalommal mosolygott, s ez a megfigyelés teljes idótartamához viszonyítva 10,8 \%-nyi ideig tartott. A diákok mosolygásának eloszlását tartalmazó ábrákból (7. ábra, 8. ábra) is jól látható, hogy a diákok a 4. foglalkozáson gyakrabban mosolyogtak, mint az 1. alkalommal. Míg az elsố alkalommal a foglalkozás közepén megfigyelhetô volt a figyelem mérséklődése, s ez megnyilvánult a mosolygások számában is, az utolsó alkalommal a mosolygások eloszlása egyenletesebb lett a beszélgetés során.

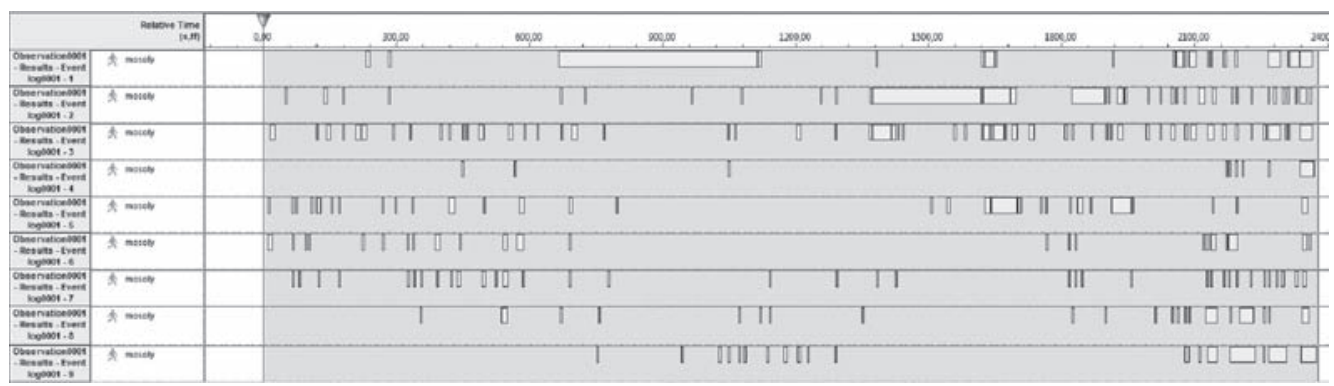

7. ábra 1. foglalkozás - mosolygások eloszlása és ideje 


\begin{tabular}{|c|c|c|}
\hline & $-\lim _{100}$ & $\sin (x)$ \\
\hline 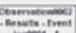 & A netos & 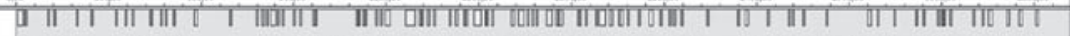 \\
\hline $\min$ & A लm & 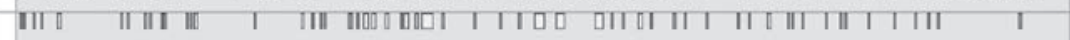 \\
\hline-1. & $A=$ & 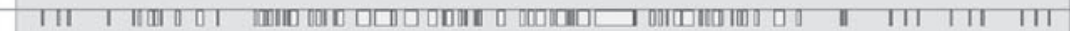 \\
\hline$=1$ & A now & 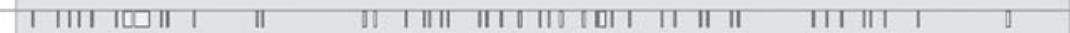 \\
\hline$\frac{1}{c t a n t-1}$ & $A=$ & 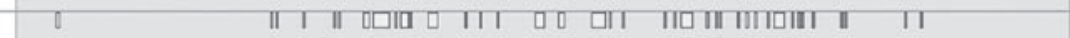 \\
\hline 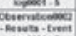 & A men & 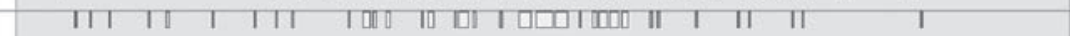 \\
\hline 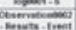 & A $\mathrm{mon}$ & 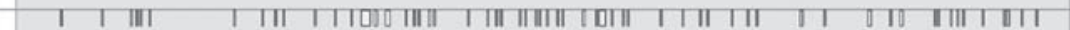 \\
\hline senter & A n.m & 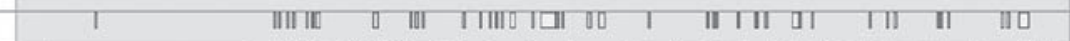 \\
\hline 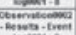 & tis & 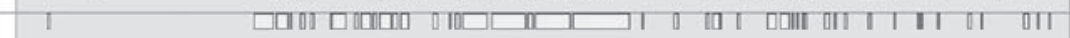 \\
\hline mation & A & $\square 000$ \\
\hline nomitition & $A$. & 1 IIDण I \\
\hline
\end{tabular}

8. ábra 4. foglalkozás - mosolygások eloszlása és ideje

A harag megnyilvánulása a foglalkozásokon egy-egy alkalommal fordult eló, akkor, amikor az iPadet a közös beszélgetés kezdete elôtt el kellett tenni. A résztvevók rosszul viselték, hogy nem lehetett náluk, azonban amikor náluk volt, mindig játszani kezdtek rajta. Ez okozta a haragot és agresszivitást az utolsó alkalommal az egyik fiúnál, valamint az elsố foglalkozáson az egyik lánynál az okozta a problémát, hogy nem sikerült elküldenie e-mailben a készített képet, valamint a többiek segítségét sem fogadta el. Míg az elsố foglalkozás esetében ez úgy nyilvánult meg, hogy a diák el akarta hagyni a termet, valamint csapkodott, és emelt hangon beszélt, addig az utolsó alkalommal a csapkodás, csupán a mimikában és a hangerô minimális emelkedésében volt tetten érhetố a felindultsága.

A diákok foglalkozás során keresztbe tett lábának Noldusból SPSS-be exportált adataira elvégzett egymintás t-próba szignifikáns eredményt nem mutat, a megfigyelés teljes idốtartamához viszonyított százalékos értéke pedig csökkent ( $\left.t^{\prime}=1,434, \mathrm{p}=0,19\right)$.

\section{Összefoglalás}

A 3. osztályos diákok tanóráinak megfigyelési eredményeinek összehasonlításából kitúnik, hogy az elsố esetben a diákok verbális, taneszközökre vonatkozó utalásai összesen ritkábban, de hosszabb ideig tartottak, mint a tanári utasítás. A tanári és a diákok utasításai is leggyakrabban közvetve az elektronikus munkafüzet használatára vonatkoztak, míg a második esetben a diákok oldaláról a közvetett, munkafüzetre utaló, a tanári oldalról viszont a közvetlen utalások voltak túlsúlyban, így az eredmények változatos képet mutatnak ezen a téren. A két megfigyelés eredményei egyeznek abban, hogy az elektronikus munkafüzet használatára történt leggyakrabban utalás az órákon, míg a hagyományos füzetre ritkán, vagy egyáltalán nem. A két osztályban a tanári és a diákok megnyilvánulásainak idóbeli aránya ellentétesen alakulnak.

A 6. osztályos diákok fejlesztố e-biblioterápiás foglalkozásainak elemzése azt mutatja, hogy a foglalkozásokon részt vevố diákok negatív érzelem-megnyilvánulásai a foglalkozások előrehaladtával veszítettek intenzitásukból, valamint gyakoriságukból. A szoftver segítségével számszerúen kimutathatóak a foglalkozások azon részei, amelyek általános pozitív megnyilvánuláshoz, vagy negatív érzelemkifejezéshez vezettek. Így elmondhatjuk, 
hogy ebben a csoportban a diákok számára a foglalkozások kritikus pontja volt, amikor le kellett tenniük az iPadet, és a nélkül folytatódott a beszélgetés. A diákok rendkívül pozitív módon reagáltak a foglalkozásokra, segítettek egymásnak, amikor az eszköz vagy a program használatával kapcsolatos problémájuk merült fel (ezt bizonyítja a diákok gyakori helyváltoztatása az 1. foglalkozáson). Ezt a segítségnyújtást a foglalkozások elórehaladtával már minden résztvevő el is tudta fogadni. Természetesen a foglalkozások, valamint a csoportok alacsony száma miatt messzemenó következtetéseket nem vonhatunk le, mindenképpen szükséges a módszer és az eszköz nagyobb mintán történó kipróbálása. Mindazonáltal a késóbbiekben mindenképpen megfontolandó, hogy a feldolgozáshoz készített felvételek készítésénél a kameraszög beállításánál vegyük figyelembe a foglalkozásvezetố azon sajátosságát, hogy gyakran megy az interaktív táblához, vagy a számítógéphez, és így gyakran kisétál a felvételról, amely azt eredményezi, hogy metakommunikációs jelzéseit nem tudjuk bekódolni a Noldus segítségével. Ezekben az esetekben nem elég két kamera, amelyek szemból veszik fel a foglalkozást, szükséges egy 3. kamera elhelyezése hátul, amely az interaktív tábla felé van irányítva.

Az elemzett esetek által megvilágított eredmények további kutatási szempontok beépítését szorgalmazzák, mivel az elófordulások gyakoriságának hátterében lévố motivációk, attitûdök feltérképezésére nem adtak lehetôséget. A vizsgálat elvégzése azonban megkívánja annak nagyobb mintán való elvégzését, mivel a felfedezett összefüggések a tanórai interakciók megértésének új szempontjait vetik fel, mint például az eszközhasználat és a kommunikációs aktivitás közti kapcsolat. Kívánatos lehet a vizsgálat kontrollcsoportos ismétlése, ahol az eltérố taneszközök tesztelése és a tanórai aktivitás vizsgálható.

\section{Irodalom}

BREDÁCS A., KÁRPÁTI A. (2012): A 14-16 éves múvészeti képzésben részesülő tanulók pszichológiai immunkompetenciája és ennek integrációja a múvészeti neveléssel. Magyar pedagógia, 112 (4), $197-219$.

Gavigan, K., (2012): Caring through Comics - Graphic novels and bibliotherapy for grades 6-10. Knowledge Quest, 78-80.

GuLYÁs E. (2015): E-biblioterápia, egy új módszer az általános iskolai gyakorlatban. Iskolakultúra. 25 (1), 127-138.

Johnson, L., Adams Becker, S., Cummins, M., Estrada, V., Freeman, A., Ludgate, H. (2013): NMC Horizon Report: 2013 Higher Education Edition. Austin, Texas: The New Media Consortium. Forrás: http://www.nmc.org/pdf/2013-horizon-report-HE.pdf (Hozzáférés ideje: 2014.december 15.)

LARSON, J., Hoover, J. H. (2012): Quality books about bullying in the young adult tradition. Reclaming Children \&o Youth, 49-55.

NemZeti alaPTANTERv (2012): Magyar közlöny. Forrás: https://www.ofi.hu/sites/default/files/attachments/mk_nat_20121.pdf (Hozzáférés ideje: 2015. január 20.)

NEMZETI INFOKOMMUNIKÁciós STRATÉGIA 2014-2020: az infokokkunikációs szektor fejlesztési stratégiája v 7.0.Forrás: http://2010-2014.kormany.hu/download/b/fd/21000/Nemzeti\%20Infokommunik\% C 3\% A 1 ci\% C 3\%B 3s\%20 Strat\% C3\% A 9 gia\%202014-2020.pdf (Hozzáférés ideje: 2014.december 15.)

Norton, T. L., VARE, J. W.(2012): Literature for today's gay and lesbian teens: Subverting the culture of silence. English Journal. 
Oliviera, A., Pinho, C. G. M. R., Monteiro, S., Sao-Marcos, A. J. R., Marques, A. (2013): Usability testing of a respiratory interface using computer screen and facial expressions videos. Computers in biology and medicine. 43 (12), 2205-2213. (Letöltés ideje: 2014. szeptember 14.)

Prater, M. A. (2003): Learning disabiblities in children's and adolescent literature: How are characters portrayed?. 47-62.

ОктATÁskutató És FejleszTó Intézet: Kerettanterv az általános iskola 5-8. évfolyamára. Forrás: http://kerettanterv.ofi.hu/02_melleklet_5-8/index_alt_isk_felso.html (Hozzáférés ideje: 2015. január 20.)

Reyna, B. A., Brown, L. F. Pickler, R., Myers, B. J., Younger J.B (2012): Mother-infant synchrony during infant feeding. Infant Behavior and Development. 35 (4), 669-677.

Ruiz-Sancho, E. M. Frojan-Parga, M. X., Calero-E., A. (2013): Functional analysis of the verbal interaction between psychologist and client during the therapeutic process. Behavior Modification. 37(4), 516-542.

SAnacore, J. (2012): Showing children that we care about their literacy learning. Preventing school failure, 188-195.

TAFFORIN, C. (2013): Time effects, cultural influences, and individual differences in crew behavior during the Mars-500 experiment. Aviation, Space, and Environmental Medicine, 84 (10), 10821086.

TeachThought Közösség (2014): A hozzáférés 1:1 modellje. Forrás: http://www.teachthought.com /wp-content/uploads/2014/03/ipad-1-to-1-model.jpg (Hozzáférés ideje: 2014, december 15.) 